UDC 327(510:4-672EU)

339.92(510:4-672EU)

DOI: https://doi.org/10.18485/iipe_ria.2021.72.1181.3

Biblid 0543-3657, 72 (2021)

Vol. LXXII, No. 1181, pp. 43-54

Review article

\title{
HISTORY AND PROSPECTS OF COOPERATION BETWEEN CHINA AND COUNTRIES IN CENTRAL AND EASTERN EUROPE
}

\begin{abstract}
Zuokui LIU ${ }^{1}$
Abstract: The cooperation between China and Central and Eastern European countries aims to promote both the development of China-EU relations and the construction of the "Belt and Road", and has gone through various development periods such as the initiation period, the golden period and the deep-water period. During different historical periods, China and Central and Eastern European countries have made positive progress in cooperation, but as the internal and external pressure increases, there is the need to further tap into the potential of bilateral cooperation. By releasing comprehensive reforms China has to free itself for more development benefits, while maintaining good China-EU relations and deepening practical cooperation in various fields, addressing in a timely manner the challenges and problems cooperation faces and promoting cooperation between China and Central and Eastern European countries in order to achieve long-term, stable and sustainable development.

Keywords: China-CEEC cooperation, "17+1 cooperation", China-EU relations, "Belt and Road" Initiative
\end{abstract}

\section{INTRODUCTION}

The China-CEEC cooperation mechanism ("17+1 cooperation") was developed from scratch, and then deepened. It has promoted practical cooperation between China and CEECs in many aspects, and also demonstrated strong development resilience. Compared with other bilateral and multilateral cooperation mechanisms, China-CEEC cooperation mechanism has its particularities. From the perspective of the development process, China-CEEC cooperation has roughly gone through three development stages: the initiation period (2011-2012), the golden period (2012-2017), and the deep-water period

\footnotetext{
${ }^{1}$ Director and researcher of the CEE Research Office of the Institute of European Studies of the Chinese Academy of Social Sciences and the Secretary General of the China-CEEC Think Tank Exchange and Cooperation Network, Beijing, China.
}

Email: liuzk@cass.org.cn 
(2017-present). Whereas both 2012 and 2017 were turning points, the former marked the official launch of the mechanism, while the latter witnessed its ups and downs due to internal and external environmental influences. At present, the cooperation between China and Central and Eastern European countries has entered a deep-water zone. How long this period will last and whether the "17+1 cooperation" will enter a new stage of development is of particular concern.

\section{THE INITIATION PERIOD OF CHINA-CEEC COOPERATION (2011-2012)}

China and CEE countries launched a formal dialogue in the field of economics and trade in 2011. After a year of preparation, the China-CEEC cooperation mechanism was officially launched in 2012. The start of ChinaCEEC cooperation cannot be separated from the background of China's rapid economic development. During the Eleventh Five-Year Plan period (2006-2010), China's rapid economic development provided an important impetus for China to develop economic and trade cooperation with CEE countries. China's gross domestic product (GDP) has achieved double-digit growth for many years, China's share of the global economy has soared from $4.9 \%$ to $9.3 \%$, and its foreign exchange reserves have reached nearly US $\$ 3$ trillion. In 2010, China's GDP surpassed Japan to become the world's second largest economy (National Bureau of Statistics, 2021). As far as Chinese enterprises are concerned, enterprises in the fields of infrastructure construction and equipment manufacturing have achieved greater development and have already attained strong international competitiveness. Therefore, when the Chinese government formulated the Twelfth Five-Year Plan, it decided to speed up the pace of Chinese companies' Going Global, strengthen their international business capabilities, and cultivate a group of world-class multinational companies; coordinate bilateral, multilateral, regional and sub-regional open cooperation, speed up the implementation of the free trade zone strategy, and promote interconnection with neighboring countries (China Peoples Daily, 2012).

2011 is the first year of the Twelfth Five-Year Plan and an important point in the development of China-EU relations. China-EU economic and trade cooperation has been continuously developing since the EU's eastward expansion in 2004. The EU has long maintained its status as China's largest trading partner, and China has also maintained its status as the EU's second largest trading partner. However, in October 2006, the European Union issued the sixth document on its policy to China, "EU - China: Closer partners, growing responsibilities", which caused some important changes in the policy leading to increase in disagreements and frictions in the fields of economy and trade and politics (Commission of the European communities[2006] 631 final). The EU kept stepping out of red 
line of China's core interests, harming bilateral relations. Since 2008, several factors such as the outbreak of global financial crisis and the European debt crisis, the Ukraine crisis, the refugee crisis, made impact on EU resulting in internal contradictions and hindering economic development. So, EU was forced to focus on internal affairs and surrounding issues. Due to the impact of the debt crisis, the CEE countries within the EU have begun to search for new development opportunities, and China's remarkable economic achievements have attracted their strong interest and great attention.

The "step up step down" power changes between China and EU, the trend of the EU's China policy development, and many problems that appeared in the relationship between the parties have caused China to re-examine its relations with Europe. While maintaining the normal development of China-EU economic and trade relations, China also needed to explore new fields and growth points of bilateral cooperation. It also needed to fully consider the EU internal differences and different demands, in order to build a more comprehensive, balanced and sustainable relationship with EU. As a result, promoting cooperation with regions within EU has become China's new perspective for development of relations with Europe. Presented with favorable chances such as the lack of time for the core European countries to take care of the CEE region, and the CEE countries wishing to develop more extensive foreign cooperation in order to overcome economic difficulties, China seized the opportunity of this time frame to develop cooperation with CEE countries and successfully initiated the China-CEEC cooperation. The China-CEEC Economic and Trade Cooperation Forum held in 2011 can be seen as part of the initiation of China-CEEC cooperation. It was also an important test before formal institutionalization. In June 2011, Wen Jiabao, then Premier of the State Council of China, visited Hungary, marking the first step in the formal economic and trade cooperation between China and CEE countries. China pointed out that CEE countries located in the heart of Europe, with extensive transportation are a bridge connecting the markets of the East and West. Chinese enterprises developing re-export trade and investment cooperation in CEE countries can save a lot on business costs, integrate into the EU's internal industrial division system, and use the EU's preferential policies to jointly extend to Western European market. By achieving mutual benefit sand win-win results, CEE countries can become the bridgehead of China-EU cooperation. At the same time, China emphasizes that CEE countries are regarded as reliable friends and important partners. Whether it is implementing the strategy of diversifying the foreign trade market or implementing the enterprise Going Global strategy, China has always regarded the CEE region as a strategic priority (Xinbua News Agency, 2011). The above statement set a good tone for the formal cooperation between the parties and raised many specific suggestions for cooperation. For example, 
China will increase its investment in infrastructure in the CEE region and establish a special investment fund. These measures laid an important foundation for the 2012 China-CEEC Leaders' Meeting.

In April 2012, China-CEEC cooperation (" $16+1$ cooperation") was officially launched with great enthusiasm of CEE countries. Poland took the lead in hosting the first summit. It can be said that the Warsaw Summit between the leaders of China and CEE countries in 2012 was a very pragmatic and efficient meeting. The proposals of this meeting included the establishment of the ChinaCEEC Cooperation Secretariat in the Ministry of Foreign Affairs of China and the establishment of a special preferential loan of US $\$ 10$ billion. The twelve actions, including the establishment of the China-CEEC Investment Fund, will profoundly affect the development process of China-CEEC cooperation in the next few years (Xinbua News Agency, 2012).

\section{THE GOLDEN PERIOD OF CHINA-CEEC COOPERATION (2012-2017)}

Different from other regional cooperation frameworks, China-CEEC cooperation entered a golden development period as soon as it was established, and the depth, breadth and influence of the cooperation between the two sides have reached a relatively high level. Although there are still some problems in cooperation, the achievements of China-CEEC cooperation are very impressive, and are embodied in the following aspects.

One is the promotion of a series of important achievements. During this period, the cooperation mechanism between China and CEE countries has been continuously improved. Various professional cooperation platforms in tourism, infrastructure, finance, agriculture, think tanks and other fields have been established with the increasing number of participants. In the context of promotion of cooperation mechanism between China and CEE countries, Chinese companies are actively investing in development of these countries. Promotion of the special preferential loans of US $\$ 10$ billion, caused continuous upscale of economic and trade cooperation between China and CEE countries. This includes a series of large-scale infrastructure and energy investment projects such as the Montenegro North-South Expressway and the Stanari Thermal Power Station in Bosnia and Herzegovina. Two promotional periods of ChinaCEE Investment Funds, also brought some small and medium-sized investment cooperation projects to $\mathrm{CEE}$ countries.

At the same time, with the encouragement of the governments of both parties, cultural exchange between China and CEE countries has developed rapidly. The number of Chinese tourists traveling to CEE countries has grown 
rapidly. Serbia, Montenegro, Bosnia and Herzegovina, Albania and other countries have adopted visa-free or seasonal visa-free policies for China. In order to further promote cultural exchanges between the two parties, China has opened a number of direct flights to CEE countries, and major Chinese financial institutions have also set up branches in these countries to serve the increasing number of corporate investments and personnel exchange. At the same time, education cooperation between China and CEE countries has also entered an active period. One by one, Chinese universities began to establish language education institutions, cooperative exchange projects, and to include Central and Eastern Europe regional and national research institutes (graduate schools). Chinese think tank institutions have begun to set up research centers and research networks in Central and Eastern Europe, which achieved great development in a short period of time. In addition, Chinese traditional medicine has also begun to enter CEE countries, which has promoted Going Global of Chinese culture. The positive momentum of cultural exchange between the parties has also aroused the enthusiasm for cooperation in CEE countries. One by one, CEE countries took turn in hosting summits. While expanding their influence, they have helped China-CEEC cooperation reach new level.

The second is embarkation on "Belt and Road" construction express train to intensify cooperation and connectivity. In September 2013, President Xi Jinping proposed the "Belt and Road" initiative, which aims to actively develop economic partnerships with countries along the route jointly building mutual trust in politics, economic integration, benefits of cultural inclusiveness, and a community of shared responsibility and destiny. The "Belt and Road" initiative has included 16 CEE countries along the "Belt and Road". These countries can fully unleash their geographical advantages and become an important hub for promoting interconnectedness. The various measures proposed by the "Belt and Road" initiative continue to empower China-CEEC cooperation and stimulate the cooperation potential of both parties. The Hungary-Serbia Railway and the ChinaEurope land-sea Express Line have been launched one after another, and so section by section China-Europe railway has led to the higher level of cooperation between the parties. In particular, the implementation of China's multiple infrastructure projects in the Balkans has promoted the rapid development of local infrastructure and has attracted widespread attention in terms of international public opinion. Following the "pragmatic cooperation", "interconnectedness" has become another important label of China-CEEC cooperation.

Third, frequent high-level visits have warmed up the cooperation between China and CEE countries. During this period, President Xi Jinping and leaders of CEE countries conducted series of frequent visits, which greatly raised the level of bilateral strategic cooperation. In 2016, President Xi Jinping visited the Czech Republic, Serbia, and Poland, and concluded or deepened strategic 
partnerships. High-ranking officials or politicians from CEE countries also took the opportunity of China-CEEC Leaders' Meeting and the first "Belt and Road" International Cooperation Summit Forum to visit China. Under the political leadership of their leaders, China and CEE countries have reached important consensus in many areas, and their cooperation has continuously produced highquality results. In 2015, at the Suzhou Summit between China and CEE countries the "Medium-term Plan for Cooperation between China and Central and Eastern European Countries" was issued. It comprehensively summarized the results of cooperation and made arrangement for future cooperation directions, pointing out that " $16+1$ cooperation" does not replace existing bilateral cooperation mechanism or platform, and that the two complement and promote each other to accelerate the improvement of the level and scale of China's relations with 16 countries. "16+1 cooperation" links up with major EU initiatives and plans to effectively promote peace, growth, reform, and civilization in China and Europe, the four major partnerships. It welcomes and supports the establishment of a China-Europe interconnectedness platform. " $16+1$ cooperation" fully grasps the important opportunities brought by the "Belt and Road" construction, continuously expands the space for cooperation, and at the same time keeps contributing to the "Belt and Road" construction.

The reasons that China-CEEC cooperation was able to make such a great progress in this period were both active participation and joint efforts of all partners and favorable external environment. First of all, China's economy performed brilliantly during the period from 2012 to 2017, and policies supporting foreign investment were introduced one after another. The "Belt and Road" initiative was introduced in such a way which promoted the rapid progress of China-CEEC cooperation. Secondly, in spite of EU increasing concern regarding the potential risks that China-CEEC cooperation will bring, such as whether it violates EU rules and whether it will cause the EU to "divide", it has not made any public interventions in terms of actual legal actions. Apart from expressing concerns on different occasions, the EU also hopes that China-CEEC cooperation can achieve practical results and promote the overall recovery of the EU economy, which, objectively, creates terms for China-CEEC cooperation. Further, although the United States pays great attention to China-CEEC cooperation, substantial intervention measures have not been made publicly. During this period, the United States was undergoing in-depth reflection and debate on domestic and foreign policies. The Obama administration began implementing the "Asia-Pacific Rebalancing Strategy" in 2012, shifting its strategic focus to Asia and decreasing its deployment in Europe. In this context, China and the United States "one in one out" attitude towards Central and Eastern Europe has to some extent prevented the two sides from having more conflicts of interest in the region. 
It is worth noting that as China-CEEC cooperation has entered the "golden period", some potential problems have gradually surfaced. For example, the results of cooperation among CEE countries are uneven, some countries have fewer achievements and unresolved financing obstacles. The implementation of related flagship projects is progressing slowly, and the trade deficit gap between some CEE countries and China continues to widen. But on the whole, during this period China-CEEC cooperation faced a better external environment and achieved unprecedented results.

\section{CHINA-CEEC COOPERATION ENTERS A DEEP-WATER PERIOD (2017 TO PRESENT)}

Since 2017, China-CEEC cooperation has still made positive progress. The actual cooperation between the parties in the fields of economy, trade and investment has yielded fruitful results. Chinese companies have continued to increase their investment in the Western Balkans, especially in investment cooperation projects in Serbia. There are also cooperation spot lights in the field of large-scale projects. The Croatian Pelješac Bridge project undertaken by a Chinese company has become China's first successful bidding project in a Central and Eastern European country that received funding from the European Union. Chinese companies continued to invest in Piraeus Port project in Greece and obtained positive returns. The Hungary-Serbia railway project was progressing in an orderly manner despite difficulties. Cooperation between China and CEE countries in terms of cultural exchange also remained at high levels. CEE countries have successively hosted the 2017 Budapest Summit of China and CEEC leaders, the 2018 China and CEEC Sofia Summit, and the 2019 China and CEEC Leaders' Dubrovnik Summit. The particularity of this summit was that Greece in 2019 joined the China-CEEC cooperation as a full member, upgrading " $16+1$ cooperation" to " $17+1$ cooperation". In addition, in 2019 China and Bulgaria upgraded their bilateral relationship to a strategic partnership, and the partnership network between China and CEE countries has become increasingly dense.

However, at the same time, the internal and external environment of China's cooperation with Central and Eastern European countries has undergone profound changes. Uncertainties in the cooperation have increased, and external factors and domestic problems overlaid, leading to increased difficulties in cooperation which gradually entered a deep-water period.

Firstly, the change in China-EU relations. In March 2019, the European Union released the "EU-China Strategic Outlook" report defining four points for China-EU relations. Namely, partners in different policy fields, negotiating partners to balance the interests of all parties, and economic competitors pursuing 
technological leadership and systemic opponents promoting different governance models. In addition, the EU has repeatedly questioned the motives for cooperation between China and CEE countries and has increased its intervention intensity, such as introducing an investment security review mechanism, and strengthening environmental reviews of China's thermal power and other energy investment projects in CEE countries. Also new restricting conditions have been added for Western Balkan countries that have not joined EU in order to guard against third-party security threats (EC COM[2020] 57 final). Especially in the areas of market access, intellectual property protection, government procurement, etc., the EU has unilaterally emphasized the reciprocity and equivalence in cooperation with China as being an interference.

Secondly, the formation of all-aspects competition between China and the United States had quite an impact on China-CEEC cooperation. Although the "Asia-Pacific Rebalancing Strategy" adopted during Obama's period was intended to contain China's overall development, but when it came to its specific implementation it adopted more gradual and flexible methods to avoid direct conflict with China. However, after Trump took office, in March 2017, he announced the formal end of the "Asia-Pacific Rebalancing Strategy" and launched a large-scale trade war against China. The US policy toward China has entered a new stage of comprehensive and direct containment of China. In this context, the United States has stepped up its intervention in the Central and Eastern European region and directly imposed pressure on the cooperation between China and CEE countries. High-ranking officials of the US government frequently visited CEE countries, spreading information security, "China threat theory" (sharp power) and other arguments, propagating that China is creating "debt trap" in Central and Eastern Europe, causing geopolitical tensions, etc. In particular, they attempted to kidnap Central and Eastern European countries' China policies on the grounds of information security. Under pressure from the United States, the duality of some Central and Eastern European countries' policies towards China has surfaced, which has worsened the external environment for China-CEEC cooperation.

Thirdly, the "murmur" regarding cooperation increased within CEE countries. Some Central and Eastern European countries have been affected by anti-China propaganda expressed by public opinion in Europe and the United States, and doubts about cooperation between China and CEE countries have risen. Some European think tanks have played a vanguard role in this. For example, the "China Influence" project and the "China Observer" project undertaken by the think tanks of Poland, Hungary, Czech Republic, Slovakia (ChinfluenCE, 2020; Choice, 2021), and a series of reports issued by the German Mercator Institute, continue to discredit China-CEEC cooperation. This caused 
public opinion to increase unceasing pressure on China-CEEC cooperation (Benner et al., 2018).

Fourthly, China's economy has entered a new normal in an all aspects, which will affect China-CEEC cooperation. Due to the profound changes in the domestic and international situation, China's economy is shifting from a stage of rapid growth to a stage of high-quality development. Long-term accumulated contradictions intertwined with new problems and challenges, causing increasing pressure on Chinese economy. In the larger context of domestic structural adjustments and changes in the growth mode, China placed more emphasis on high-quality development of cooperation in the field of foreign investment, economy and trade, simultaneously bringing benefits to long-term economic development. However, such adjustments will inevitably cause some short-term pains, which will certainly impose pressure on China-CEEC cooperation. In particular, the outbreak of the new coronavirus epidemic at the end of 2019 has further increased the resistance towards economic development and investment cooperation between China and CEE countries, making China-CEEC cooperation linger in the deep-water period.

\section{PROSPECTS AND COUNTERMEASURES OF CHINA-CEEC COOPERATION}

The China-CEEC cooperation, being an important undertaking of foreign exchange, will inevitably encounter some twists and turns, but its prospects are undoubtedly bright. To solve the current difficulties of cooperation with CEE countries, China needs to take care of both its domestic and foreign affairs. It must not only address its own affairs well, but also further good resolutions of issues with CEE countries such as trade deficits and access to agricultural products. At the same time, China has to comprehensively and effectively deal with problems and challenges that changes in relations with EU and US have brought about for bilateral cooperation.

Firstly, China has to further benefits of freer cooperation with foreign countries by comprehensively deepening reforms. Facing the complex situation at home and abroad, China should continue to make efforts in market access, intellectual property protection, and domestic structural reforms, so that CEE countries can see that they can gain more opportunities from China's increasingly open market. In addition, Chinese overseas companies, especially companies that have previously invested in CEE countries, should make full use of the benefits offered by the policy of comprehensive deepening of domestic reforms. These companies need to continuously promote their own optimization and upgrade, and increase investment in CEE region in order to boost local economic and social development. 
Secondly, there is the need to further tap into the development potential of cooperation between China and CEE countries and solve the existing cooperation problems. On the one hand, China and CEE countries should maintain good cooperation in the field of economy, trade and investment, further increasing the investment of private enterprises. China should deepen the cooperation potential of CEE countries in high-precision digitalization, intelligent machinery manufacturing and other industries, especially to promote connecting of related industries "Invisible champions" in order to fully tap into complementary potential of the parties in market, knowledge and resources. It should strengthen mutual cooperation in cultural exchange, and jointly create cooperation results in the fields of animation games, film and television dramas, variety shows, tourism and education, thus achieving "win-win" effects in cultural industry and society. On the other hand, China and CEE countries should promptly and favorably resolve problems in cooperation. China needs to address the concerns of CEE countries in a timely manner, and actively resolve various problems accumulated or emerging in bilateral cooperation, especially those involving trade deficits, imbalanced investment projects, and difficulties in accessing agricultural products. At the same time, both sides need to work hard to strengthen mutual political trust, deepen economic and trade cooperation, and improve the level of cultural exchange, so as to set China-CEEC cooperation on a path of high-quality development.

Thirdly, there is maintenance of the overall situation of China-EU relations and aiding China-CEEC cooperation. Economic and trade relations are not only the top priority of China-EU relations, but also the foundation of relations between China and CEE countries. China and the EU should further consolidate the achievements of the negotiations regarding China-EU Geographical Indications Agreement, accelerate the progress of the China-EU investment agreement negotiations and strive for its early completion and signing of the treaty. Various parties created conditions to initiate the feasibility study of the China-EU Free Trade, also improving conditions for China and CEE cooperation in economy, trade and investment. At the same time, since the industries of CEE countries are deeply integrated into Europe, China should promote more achievements in the field of industrial chain development and industrial cooperation with important European countries, assisting China and CEE countries cooperation in industrial chain and other fields. In addition, China and the EU should continue to use the potential for cooperation around important initiatives such as the "Belt and Road", create multi-dimensional connectivity, and enhance the level of practical cooperation. In this process, Central and Eastern European countries can make full use of the advantages of geographic and logistics hubs to promote China-EU connectivity and cooperation. 
Fourthly, seizing the new chances to find opportunities for China-CEEC cooperation. Since the Trump administration came to power, it has pursued the "America first" policy, regardless of the opposition of the international community and even EU allies, and held high protectionism and unilateralism, which caused dissatisfaction of EU and many CEE countries. At the same time, China's policy concept of "seeking common ground while preserving differences" and "mutual benefit and win-win" has been more attractive to Europe, including CEE countries. As a response to US pressure China should seize this opportunity, and act on its advantages, actively developing close partnerships with the European Union and its member states, developing cooperation in the fields of $5 \mathrm{G}$, investment and business, and cultural exchange, and use higher levels of practical cooperation with both Europe and CEE. Under the impact of the new coronavirus epidemic, European countries got into great trouble, and China actively aided, within its capacity, European and CEE countries by dispatching medical assistance teams to Italy, the United Kingdom, Serbia. Thus, strengthened international cooperation in the field of public health with the European side and further stabilized confidence of CEE in cooperation with China.

On the whole, the current CEE countries' demand for cooperation with China are still flourishing. China should focus on the two basic directions of promoting the development of China-EU relations and advancing the construction of the "Belt and Road": opening up to high-quality practical cooperation and brining more benefits through deep reforms and broader opening to foreign countries , while actively maintaining the general situation of China-EU relations, deepening China-EU cooperation in various fields, and promoting China-CEEC cooperation to achieve long-term, stable and sustainable development.

\section{REFERENCES}

Benner, Thorsten, Jan Gaspers, Mareike Ohlberg, Lucrezia Poggetti, and Kristin Shi-Kupfer. 2018. “Authoritarian Advance: Responding to China’s Growing Political Influence in Europe", Global Public Policy Institute and Mercator Institute, February 5. https://www.gppi.net/media/Benner_MERICS_ 2018_Authoritarian_Advance.pdf

China Peoples Daily. 2012. "Hu Jintao's Report at the 18th National Congress of the Communist Party of China", November 8. http://cpc.people.com.cn/ $\mathrm{n} / 2012 / 1118 / \mathrm{c} 64094-19612151 . \mathrm{html}$

ChinfluenCE. 2020. "Engaging China in 17+1: Time for the ACT Strategy", Accessed 14 January 2021. www.chinfluence.eu/.

Choice. 2021. "China Observers in Central and Eastern Europe", Accessed 14 January 2021. https://chinaobservers.eu/. 
Commission of the European communities. 2006. EU - China: Closer partners, growing responsibilities, $\operatorname{COM}(2006) 631$ final, Communication from the Commission to the Council and the European Parliament, October 24. http://aei.pitt.edu/38107/1/COM_(2006)_631.pdf

[EC] European Commission. 2020. Enhancing the Accession Process - A Credible EU Perspective for the Western Balkans, COM(2020) 57 final, Communication From The Commission To The European Parliament, The Council, The European Economic And Social Committee And The Committee Of The Regions, February 5. https://ec.europa.eu/neighbourhood-enlargement/sites/near/files/enlargement-methodology_en.pdf

National Bureau of Statistics of China. 2021. Accessed 13 January 2021. http://www.stats.gov.cn/tjsj/

Xinbua News Agency. 2011. "Wen Jiabao's speech at the China-CEEC Economic and Trade Forum", June 26. http://www.gov.cn/ldhd/2011-06/26/content _1892867.htm

Xinhua News Agency. 2012. "China's twelve measures to promote friendly cooperation with Central and Eastern European countries", April 26. http:// www.gov.cn/ldhd/2012-04/26/content_2124352.htm

\section{ISTORIJA I PERSPEKTIVE SARADNJE IZMEĐU KINE I ZEMALJA CENTRALNE I ISTOČNE EVROPE}

Apstrakt: Saradnja između Kine i zemalja Centralne i Istočne Evrope koja ima za cilj da ujedno promoviše razvoj odnosa između Kine i Evropske unije i razvoj Inicijative Pojas i put, je prošla kroz različite razvojne periode kao što su inicijalni period, zlatni i period "duboke vode". Tokom različitih istorijskih perioda Kina i zemlje Centralne i Istočne Evrope su napravile pozitivan napredak u saradnji, ali kako se unutrašnji i spoljašnji pritisci uvećavaju, postoji potreba da se bolje sagleda potencijal bilateralne saradnje. Stvaranjem sveobuhvatnih reformi, Kina se mora otvoriti za veće razvojne koristi, uz održavanje dobrih odnosa između Kine i EU i produbljivanje praktične saradnje u različitim oblastima, te blagovremeno rešavanje izazova i problema sa kojima se saradnja suočava, i promovisanje saradnje između Kine i zemalja Centralne i Istočne Evrope u cilju postizanja dugoročnog, stabilnog i održivog razvoja.

Kjučne rečr: saradnja između Kine i zemalja Centralne i Istočne Evrope, saradnja $17+1$, kinesko-evropski odnosi, Inicijativa "Pojas i put"

received: 02.01.2021

accepted: 08.03 .2021 